Journal of Social Sciences 8 (2): 207-215, 2012

ISSN 1549-3652

(C) 2012 Science Publications

\title{
Role of Virtual Education in Higher Education from the View of Existence Philosophy
}

\author{
Saeid Zarghami Hamrah \\ Department of Philosophy of Education, Faculty of Psychology and Education, \\ Tarbiat Moallem University, No. 49, Mofateh Ave, Tehran, Iran
}

\begin{abstract}
Problem statement: The problem of present study is to investigate the role and place of virtual education in attainment of educational goals by students which can be deduced from views by prominent existence philosophers. Approach: The research methods used are qualitative content analysis as well as practical syllogism. Results: Regarding the first goal, attending to individuality and students' authenticity, it is explained that virtual education provides many chances for study, job and future life, but reviving, maintaining and developing the traditions and social and authentic culture that is specific to a community are possible through negotiation and social interactions like face to face interaction between teacher and students. Regarding the second goal, passing from nihilism, the conscious and free cooperation of student necessitates creating chances for critically questioning the process of virtual education. To this aim, it is essential to consider virtual education as means and it should not be changed into educational goal or its determinant. Conclusion/Recommendations: In the discussion and conclusion also the implications of the results of the study such as the priority of questioning technological paradigm over questioning the manner of reforms by employing it and taking a holistic view in application of IT instead of a one-dimensional technical view are presented.
\end{abstract}

Key words: Virtual education, higher education, educational goal, existence philosophies, technical view, philosophical inquiry, information technology

\section{INTRODUCTION}

The pervasive and significant role of technology and its latest product, information technology, in different fields of human life including the field of higher education and its wide consequences necessitate intellectual or philosophical inquiry of the nature and origin of information technology and the methods and goals for its application and development. Questions about technology return back to ancient Greek (Hanks, 2009) but by the expansion of new technologies, including information technology, philosophical inquiry of these technologies is also increased (see for example: Kierkegaard, 2010; Jaspers, 2009; Marcel et al., 1980; Marcuse, 2002; Lyotard, 1984). Among these thinkers the role of existence philosophers is more basic and more prominent. Existence philosophy was emerged out of ideas by Nietzsche and was developed by thinkers like Heidegger, Jaspers, Marcel and Sartre in the twentieth century. The ideas of these philosophers are not parallel but all of them emphasized on union of thinking with deep and real experiences of human life and existence in reaction to ideas by many philosophers who aimed at passing over precise and individual characteristics and to approach realities beyond time and place.
Based on this ground, the present study aims at investigating the role of virtual education in attaining some of the goals that can be planned for education in higher education by focusing on basic ideas of existence philosophers. It is worth mentioning that investigating this issue in the higher education is more realistic and significant than the educational grades prior to university, because the depth of what existence philosophers state is in a way that may face many difficulties for application to educational grades prior to university.

Regarding the significance of this study, two points could be raised according to the mentioned discussion: first, virtual education is a novel idea for which the consequences and results are not comprehensively considered philosophically. And it is more significant and delicate in comparison to other applications of IT such as industry or economics because the subject is not one aspect of human being, for example economical aspect, but it is human being and his education. Second, existence philosophers have set comprehensive, humane and deep goals for education by highlighting individuality and human existence (Blake, 2003). Investigating the role of virtual education in attaining these goals by students is of high importance and it is a step forward for clarifying the place of IT and virtual education in higher education. 


\section{J. Social Sci., 8 (2): 207-215, 2012}

The results of this study provide a theoretical framework to be applied by policy makers and curriculum developers in employing virtual education in universities according to philosophical foundations.

\section{MATERIALS AND METHODS}

In order to compare the views by existence philosophers with the aim of planning some educational goals for higher education, the contents of valid and relevant documents are analyzed qualitatively. Concerning the fact that there are various methods for qualitative content analysis (Given, 2008), the present study applies comparative analysis. As (Rihoux, 2006) believes, comparative analysis is a comparison between subjects, predicates, collections, individuals, groups or time periods which reveals the similarities and differences between them. The main part of constant comparative analysis is called "constant comparative analysis" and it is said that" ":"... It involves taking one entity or piece of data, such as a statement, an interview, or a theme and comparing it with others to identify similarities or differences. By isolating these aspects, it is then possible to develop a conceptual model of the possible relations between various entities "(Given, 2008, p. 100). In the present study, the concepts or predicates describing the views of existence philosophers about the nature of human and his life are compared by the method of constant comparative analysis in order to deduce some of the goals of higher education by using practical syllogism as one of the methods for philosophical inquiry (Edmund, 1991). At last, the role of virtual education in attaining these goals is investigated from a philosophical point of view.

Existence philosophy: From a long time ago some of the philosophers have tried to go beyond all of the trivial and individual characteristics and to reach the realities beyond the time and place and whatever that is temporary. From the 19th century on, some of the other philosophers have emphasized the link between thought on the one side and deep and real life experiences and human existence on the other side as a reaction to such process in the history of philosophical thoughts which they claimed to be far away from human's real existence and life. That is why they are called existence philosophers. As they believe the condition of every individual, concerning the circumstances that surrounds him, is unique. Every scientific or philosophical system that tries to understand the condition of human being cannot illuminate the individual condition in relation to his real life and help him in his self-fulfillment.
For example, (Kierkegaard, 2010), as a reaction to the Hegel's ideas, uses the word existence to describe the human's being. As he believes, human being existence is the total unity and the though, with all the importance, is only one of the human powers and is one of his dimensions. Therefore, if this dimension is separated from its roots, which is the existence, or in other words if the human existence is only limited to the thought his life will be devoid of passion. Jaspers (2003) considers Nietzsche, who is against Kierkegaard in some of the aspects, as similar to him because he also emphasizes the relationship between thought and human's real life. He writes about them: "Both questioned reason from the depths of Existent ... [as they believe] but the thought of man must be the house in which he lives or it will become perverted (pp: 25-26). Marcel's criticism about some of the celebrated philosophers focusing on abstract concepts and their inattention to human existence and condition in real life is also in the same track (1985). Heidegger and Stambaugh (1996) describing the human's being refers to possibilities such as death, concern and anxiety which can provide a context for escaping the routines and ignorance. The authentic human is the one who bravely preserves concern and anxiety and looks at death as a possibility that demolishes all the other possibilities of life. As Sartre (2001) also holds, human's being is prior to his essence and since he is a free being for himself, he is able to create the values and these values build his essence.

Craig (2005) claims that there are wide differences among the ideas by the existence philosophers but all of them underline common points in explaining human existence; first, there is no predetermined goal or essence for human being and he determines his essence through his own behaviors. Second, human has free will and no social or biologic element can prevent from this freedom; rather he can control and apply these elements in his way to freedom and hence should accept the responsibilities for his actions. "Consciousness" about various possibilities in life and human freedom in choosing specific possibilities and rejecting others is actually "consciousness" about responsibility and hence is combined with panic, care and anxiety.

As it is clear, there is a connection and coherence between the mentioned points in a way that they could be regarded in relation to each other and they could also be categorized. For example, the necessary condition for identification of human nature by himself is his freedom. Freedom could also provide a ground for human authenticity. In the following some educational goals are presented according to the common explanation of 


\section{J. Social Sci., 8 (2): 207-215, 2012}

existence philosophers for human and his place and the categorizations they offer. These attainable goals are inferred from the ideas of existence philosophers and in each specific case the role of virtual education is considered for the achievement of that goal.

First goal: Emphasis on individuality and authenticity: Existence philosophers emphasize on individuality and authenticity and therefore they can be considered as one of the existential education goals. For example, Kierkegaard by reacting to this idea of Hegel that individual freedom is abstract, fake and unreal, argues that human's individual is superior to human's kind (Craig, 2005). In more simple words, talking about individual based on general characteristics of the group, society and human kind is neglecting exclusive characteristics of each human being. As he believes, human life is choosing; a choice which involves risk and since he is the result of these choices, he is the creator of himself. As (Nietzsche et al., 2006), the life of authentic human has an internal power that is action not reaction; hence he can change the external conditions toward himself and apply them. Heidegger and Stambaugh (1996) also believes that natural characteristic of human existence or Dassin is to be with others, to resemble others and even to keep resembling them: At the first Dassin eats, wears, says, writes and behave just like other Caseins. The role of others in the life of Dassin can be in a way that nothing remains of him and his individual characteristics. On the other side, by the loss of Dassin in "others", they also disappear and what remain are routine, similarity and superficial and self-alienated or inauthentic people. But it is not so that he remains in this condition for ever. On the basis of this ground, Heidegger talks about other characteristics of Dassin like care, anxiety and death. In the condition of care and anxiety ordinary idea and behavior that are based on accepted preassumptions of all is not possible but his reaction, or in more precise words his action, would be unique and authentic. Thinking and care about the issue that he is a passer and goes to death is also a ground for releasing from routine and being oneself and becoming oneself. Sartre (1969) also talks about two kinds of being: "being in itself" and "being for itself", "being in itself" is just there and it is what is there. But "being for itself" that is human being is what is not but it wants to be. Human constructs his own nature and essence and is responsible for it and this responsibility along with its basis that is indefinite freedom is terrifying. As Sartre believes in order to release from the panic caused by freedom and responsibility human being deceives him. For example, he refuses his freedom and responsibility and attributes the way that chooses for his life to the fate. Jaspers (1989) also believes that the result of proceeding science is knowledge and the result of proceeding philosophy is awareness. This awareness is a beginning for taking advantage of freedom, being oneself and becoming oneself. He adds that although human is constantly in conditions that are not selected by himself, but he can accept them and use them in the way to constructing himself and by doing this he can transcend them. In his beliefs (Craig, 2005) becoming oneself and transcendence is possible in two states of "existential communication" and experiencing "boundary situations". Now the role and place of virtual education can be considered in relation to such states.

Focusing on student as a beneficent society member and the role of virtual education: The existence philosophers believe interpretation of what has happened in the past could affect our lives. What is called history by Heidegger and Stambaugh (1996) is also a set of historical factors and conditions that allow our present understanding. In the same line, following the ideas by Kierkegaard, Jaspers (1989) distinguishes between community and society. Community is an institution that is formed and developed as a result of historical evolution and it has unique traditions and past; in fact it is unique and different from other communities since it constantly depends on its past and is aware of it. Society, which could be created by plan, has no past and it is not unique and historical since it could be planned and built the same way as the other societies. But it seems that every society that takes historical reality is a community due to having historical background. At this point the determining factor would be the strength and weakness of the foundations. Therefore, if a community is more dependent on and aware of its past it is more fundamental. Regarding the same point, Jaspers claims that the dominant conditions in each community throughout the history as well as the evolutions, which could be called as historical soul of society, is unique and specific to that community. Jaspers believes that historical soul is represented in the personalities and behaviors of the community members. Accordingly, one of the goals of education should be arousing and preserving historical soul in the students through cooperation in daily life, experiencing the speaking codes and personal interactions such as interacting with the university teacher (ibid.). In the same vein, with reference to the ideas of Kierkegaard, Jaspers (Hamrah and Behrangi, 2010) indicates that "educating learners as beneficial community member" on the one side, means preparing them for job, work and future life and 


\section{J. Social Sci., 8 (2): 207-215, 2012}

this aspect can be planned precisely and attain the mentioned goal by systematic and stepwise implementation. On the other side, it means reviving, maintaining and developing the traditions and society's historical soul through ways like cooperation in daily life, experiencing how the people of that society talk and personal and social interactions like interacting with teacher's personality that Jaspers calls "existential communication" (Craig, 2005) and claims that being oneself and becoming oneself is possible only through such communication. Furthermore, in such communication that is cooperation and personal and social interaction, individuals become aware of their society's past and would be connected to it.

Concerning the first aspect that is preparing students for job, work and future life, virtual education has provided many chances: virtual education brings positive and significant results for students in academic and professional fields. Now, on the one hand, the fast and wide availability of information has decreased student's needs for information and, on the other hand, it saves the time for obtaining information. This technology facilitates the process of education and also can be in service of novel educational ideas as a useful instrument. For example, we can mention access to huge bulk of information, multimedia design for education and virtual education. By using this technology educational software's can be offered that are designed based on novel educational ideas like cooperative learning, learning in action, learning through playing and learning beyond the university. But, along with these results, virtual education has changed the life pattern of teachers and students. For example, in order to satisfy their informational and even social needs they resort to virtual communications like chat and email (Laurie, 1997). The expansion of this flow and omitting the personal interaction between teacher and students is considered a challenge for the second aspect that is reviving, maintaining and developing society's historical soul in the students.

for further clarification it could be said that each society maintains its own specific history and culture which could be represented in the personality of teacher. The historical soul, which is revealed through teacher's personality in his/her interaction and communication with students, could be grasped and felt by the students. In this way, personal and face to face interaction takes a significant role in education from the viewpoint of existence philosophers. This type of interaction is considered as one of the conditions for arousing and developing historical soul in learners. But is not the only condition, so the important issue is the contexts that could lead to other essential actions and activities for the mentioned goal. Virtual education is criticized because it does not establish a context for such an interaction. It does not mean that face to face interaction is the only necessary condition for arousing historical soul in learners. This point necessitates further investigation and discussion. Pagani (2005) emphasizes the necessity of face in interface. As he believes, beyond biological functions (seeing, hearing, smelling and tasting), the face creates a set of signs such as the general facial structures and expressions, wrinkles, crying and flushing that are necessary in human interactions in social life. Taking another step, (Pagani, 2005) claim that bodily presence, including body states like touching, smelling and tasting, assume some role in social communications of human beings, so face to face interaction creates a rich and essential context for social communications and attachments among the human beings.

Virtual communication lacks some of the abovementioned aspects that are characteristics of face to face interaction. This is the reason (Prosser and Ward, 2000) believe that virtual communication is artificial and disembodied and hence shallow and irresponsible which contradicts a passionate and deep communication. On the other hand, they take virtual communication as a comfortable and unbounded one which is the reason for increasing attraction and pervasiveness toward this type of communication among students and teachers.

Emphasizing individuality and authenticity of students and the role of virtual education: Existence education requires the teacher to consider each student individually and develop him/her to be authentic. From an existence point of view, authentic students select their own selves and lives in coordination with the values they had adapted; establish an endless relationship with them; appreciate life with passion; recognize the significance of silence and loneliness; and bravely accept that the only absolute thing in the future is death. They know that reason is not a proper logic for behaving in certain ways and this is not what their nature strives for. In fact they are their own previous imaginations about themselves and the present behaviors. In such conditions they face contradictory possibilities and therefore, as Heidegger and Stambaugh (1996) states, they experience "unheimlich" and the reaction to these conditions is anxiety. An authentic student is someone who maintains the anxiety instead of escaping from it, for which one of the representations is following and acting the same as others. With anxiety one could not decide ordinarily and without any reflection. This anxiety changes the 


\section{J. Social Sci., 8 (2): 207-215, 2012}

manner of doing things. It means that learners would no more abandon a goal or plan due to lack of meaning appreciated by public and their answers are unique.

Nevertheless in technological system of virtual education each students is exposed to a mass of information the same as other students. According to the information that are provided for student, they similarly think and produce science by using the novel scientific principles present this to other people as a information. This type of thinking is scientific and general and includes overall validity. In contrary, (Jaspers, 1989) maintains that "becoming self" and "finding self"_require a type of thinking which does not take public, scientific and generally valid meaning ( $\mathrm{p}$. 233). As it was mentioned, "becoming self" and "finding self" are achieved in border situations; border situations are the experience of war, failure, guilt, suffering, love and a sense of God presence that individual faces in the apex of happiness or in the depth of sorrow, grief, or failure. Jaspers argues only in border situations human being understands who he really is (ibid., p. 229). The mentioned experiences are, on the one side, subjective and unique to each individual and, on the other, are bodily experiences directly or indirectly. If we consider the technological era as the post-biologic era and maintain virtual education without bodily presence, the role of experiences such as war, failure, suffering and even love fade away as biological and bodily experiences in the process of education. In this manner the necessary backgrounds for "finding self" and "becoming self" are reduced.

Another point could also be raised on the issue of individuality and the role of virtual education. (Cheserbo, 1999) proposes that each learner creates his/her own specific communicational system in the virtual environment. He argues that searching the Internet by learners is not done with the same goal and therefore the knowledge foundations of such system are unique to each learner. Ladriere (1998) refers to separation of learners as one of the consequences of IT. This separation gives learners that chance for silence and facing their selves. In contrast, (Murphy and Pardeck 1985) call the communication through technology as homological discourse (p, 102). Inspired by Habermas, they hold that homological discourse results from common mentality about a specific meaning. That is the message sender and receiver, each with their own unique nature, is already equipped with the same program. This type of discourse is followed according to universal, non-historical, logical and lingual principles. They believe that technological education is an outstanding example of homological discourse and the information is provided by an agent that is programmed based on universal, non-historical, logical and non-interpretive principles. As a result, all learners receive the information in the same format.

Second goal: passing nihilism: Nietzsche stars by criticizing his contemporary cultural condition. As he believes (2006), higher human values such as truth and honesty that were first gifted by Zoroaster to human kind are discredited now and instead of them inability, pathos, hypocrisy and degrading are considered as values. Nietzsche calls this inversion of values or, in other words, discrediting the highest previous values as nihilism. He believes that the way to escape this condition is not returning to the previous values but creating novel values. In this way he thinks that it is good to consider nihilism as one stage to be passed.

Describing his contemporary cultural condition, Kierkegaard indicates to other characteristics like superficiality, abstract thinking and lifeless, being stranger to loneliness, lowering love to lust and domination of universal beliefs from other point of view. He believes that media have played a considerable role in the formation and development of these characteristics as well as dis-commitment of human beings. Regarding the same point he writes: "nowadays, everyone knows everything, but no one is committed to anything" (Prosser and Ward, 2000). In such conditions Kierkegaard thinks that his prophecy is elucidation and calling everyone to freedom and leaving this condition.

Marcel (Marcel et al., 1984) also believes that the characteristic of the present era is viewing anything, including human being, from the window of utility and he introduces this condition as the consequence of new technology development as well as disappearance of individual existence. He tries to take a step in awakening and escaping from this condition by describing and elucidating the present condition of human being. Heidegger and Stambaugh (1996) also thinks that human being has reached a technological understanding of being in the modern era. He (2010) considers the expansion process of new technology the same as the process of production, storage and expansion of energy that takes functionality and advantage as the only evaluative criteria. He states invasion to the nature as one of the tacit consequences of such process. As Heidegger believes, the essence of new technology is not neutral. He takes the German word "Gestell", meaning frame and case as the essence of new technology and believes that the essence of new technology is "framing" and "shaping" which encompasses objects as well as human beings. To further illuminate this idea, he describes the 
technology and industry of and and news and publication. After cutting the trees and changing them to and this technology finally produces news ands which frame public thoughts and shape it.

It seems that Heidegger is inspired by Kierkegaard in his criticism of public opinions by the press. Kierkegaard (Prosser and Ward, 2000) maintains that information technology and communication in $19^{\text {th }}$ century in west increasingly supplied the information and offer any type of information to anybody. In this manner it eliminated meaningful differences among various issues and as a result the mass got interested in any issue and had no real and passionate commitment. Although the press expanded the superficial interests and relationships among the people, it decreased the traditional depth that used to be formed in communities on the basis of sympathy. Therefore, the present era is an era of separation and indifference.

Dreyfus (2009) and Dreyfus and Spinosa (1997) following the ideas of Kierkegaard, concludes that nowadays information technology has functionality similar to media in nineteenth century. In this way it seems that if the goal in the process of virtual education is limited to production, storage and expansion of information and it only emphasizes on utility of information for resolving daily problems, welfare, joy and pastime, then student also would be a part of technological system and a means in the service of its expansion. Then the accuracy and inaccuracy of his behavior would be evaluated by criteria, including functionality, that are defined by this system.

As examples from the present culture of students, their main concerns and their information consumption could be revealed according to evidence from the chats through the Internet and the text Messages (SMS) that are exchanged among them by cell phone or electronic mail. In such condition the students expect IT to offer peacefulness and further flexibility and functionality for relieving from daily concerns and tensions. He believes that this is our present condition since we want to spend our time in the most functional way by applying IT and the progress criterion in technological system is merely functionality. Functionality is the leading criterion in the field of science and technology. But, as it was discussed, many existence philosophers such as Kierkegaard, Nietzsche, Jaspers, Marcel and Buber believe that in the social field the ethical codes must be dominant. As a consequence of widespread acceptance of functionality as criterion and its penetration to social field, ethics would be suppressed as an aspect of life and there would be no difference including specific meaning or content.

Based on such a ground, if one of the existential education goals is considered to be passing nihilism, it could be asked that: what can be done in order to escape this condition?

It seems that the way to escape this condition is changing the view and rethinking about the present condition and the concepts like functionality, goal and life meaning and following that limiting the territory of legal function of information technology. Regarding this point as (Borgmann, 2000) believes, identifying the capacities and limitations of information technology can change it to a useful means for development of welfare and facilities and increasing the educational advantages: in the previous sections some of the capacities are mentioned. But, being aware of limitations of information technology and virtual education is also necessary. For example, Borgmann believes that information is not only technological and student should take advantage of other types of information that is natural (information that the learner interacts naturally and without the intervention of any artificial issue) and cultural (information that are in the form of maps, charts and cultural symbols) through bodily experience and direct involvement with nature and society. On the other hand he highlights that IT should serve education as a beneficial means and it should not be considered as an end. He believes that by regarding IT as means we could question the reason and necessity or why of applying IT for education rather than raising questions about the manner or method or how of application.

Therefore, it seems that virtual education and the solutions for its expansion should not be taken as independent from education or as an educational goal. The first step is to define the goals and purposes of education and then the role of virtual education needs to be clarified in relation to those goals and purposes. By doing this, the selected educational goals would be the focus of attention through which the necessity and role of IT and the application methods could also be defined.

\section{RESULTS AND DISCUSSION}

In the present and the virtual education is investigated with regard to two educational goals in higher education from the viewpoints of existence philosophers. Concerning the first goal, that is attending to students' individuality and authenticity, it was discussed that virtual education has created numerous chances for education, job and future life for the students; nevertheless, arousing and maintaining the original and historical traditions and culture specific to each community could be are possible through talking 


\section{J. Social Sci., 8 (2): 207-215, 2012}

and social communications such as face to face and personal interaction between students and teachers. Therefore, the teacher training system should develop teachers who are the representative of specific historical traditions and culture of their community and also offer opportunities for interaction with students in university and society in order to create a background for arousing and preserving the traditions in students. Jaspers argues that achievement of such goals is not possible by scientific planning since those phenomena could be planned scientifically which are publically acceptable or, in other words, objective and universal while tradition and original culture are exclusive, mental and local. Due to the fact that virtual education is from far away and lacks presence, it limits the interacting chances between students and teachers in the places such as classroom, university and even society. Consequently it reduces the chances for maintenance and development of historical soul in learners. The other important point to be raised is that such a goal could not be attained merely by planning scientific and public curricula in the process of virtual education and even personal and face to face education. Here the focus is not on the benefits of scientific planning rather it is the significance of face to face communication and its role in arousing and developing historical soul as a ground for students' authenticity. Subsequently, there would be opportunities for students, who are representatives of historical traditions and culture of their society, to attain authenticity.

Regarding the second goal, that is passing freely from nihilism there are also some points to be mentioned. If the expansion of virtual education is introduced as the necessary condition for educational system progress and the role of students and their level of achievement is defined according to this criterion, then the educational system would limit learners' awareness and freedom to protecting technological educational system. In such conditions learners are expected to play their role, which is supporting technological educational system, in the best way. In this type of educational system, the behaviors that are in agreement with the criteria for expansion of technological educational system would be valued over the behaviors that represent individual and internal values of students. Therefore, the conscious and free cooperation on the side of students require chances for critically questioning the virtual education. To this aim, it is necessary to consider virtual education as educational means rather than an end or determining factor. Only in this condition, the goals that are selected for education could be judging and evaluating criteria for other selections and decision in the field of education. Educational goals create criteria that could be applied in critically investigating the role and necessity of employing virtual education as well as the range and methods of applications. We should not be passively attracted to IT and the rationalism resulting from it because in these circumstances the students' cognition, behavior and learning would take a technological nature. In this way, the students' lives would be also technological and they should be obedient to the origin of novel social order, which is IT, since they merely supply the force for social order and are not capable of changing it. In other words, the students would be slaves to IT. Consequently, the interpretation and criticism of technology would not be possible in the field of education. It should be underlined that although IT is the result of human thinking that could provide learners with the information required for thinking, it is neither the thinking and knowledge nor the final means for knowledge evaluation. But it is another form of human action that could be criticized and challenged by him. The value and significance of thinking maintains its place with the introduction of IT to the field of education. This value might even be reinforced since the availability of a bulk of information through IT necessitates students to distinguish between supposed and real knowledge.

\section{CONCLUSION}

The following practical applications and implications are suggested to experts and curriculum developers in higher education according to the results of the present study.

The first necessity is the priority of questioning technological paradigm over questioning the manner of reforms by employing it. The majority of recommendations proposed for applying virtual education presuppose the acceptance of technology paradigm. It means that by accepting the capability of IT in improving the educational system they turn their attention to questioning the manner of application. These criticisms mainly deal with the undesirable consequences of IT and following that offering some solutions for overcoming them. In other words, these questions are from how type. But the more fundamental questions to be raised are of what and why type about IT. In this approach the goodness or badness of technological paradigm or its range of application are questioned. As an example of these types of questions we can mention "what is the role of virtual education in higher education?" In the answers to these categories of questions, such as the results of the present study, some necessities are indicated.

As it was presented, the role of IT in education is facilitative rather than productive. In other words, IT plays no role in knowledge production and does not 


\section{J. Social Sci., 8 (2): 207-215, 2012}

determine its foundations such as principles, basics, content and goals. For example, when we talk about designing educational softwares according to the learning theory of Dialectic Constructivism, the foundation and basis are the linguistic theory by Vygotsky regarding the mental development and learning and this idea is supposed to be applied in education through technological means. Therefore, as far as the problems of education are related to foundations, IT could not offer solutions. If the higher educational system is confronted with foundational failures that has existed before the introduction of computer to the classroom or are not managed prior to the formation of virtual education and by the introduction of computer and the development of virtual education these problems would not be solved. One of the problems raised in this study is how to benefit the deep ideas of existence philosophers in higher education system. The goal of education goes beyond acquiring knowledge and expertise as well as cognitive and intellectual development and these are defined taking a deep view toward the nature and being of human kind.

For further illumination of the discussion it could be added that IT is not a determining factor for educational goals. By this view, technological paradigm is reduced to educational means and is applied in expanding educational equipments and could not go beyond these borders. As far as the current and prevalent role of IT is accepted without any revision and we suppose that it establishes rich and endless opportunities for students' lives and we are fascinated by its numerous promises and hopes, we have overlooked the foundations for technological actions that are human nature and its representations such as thinking, feeling and the achievements throughout the history. As the result, those achievements which emerged throughout the history before novel technologies, including IT, are downgraded and might seem restrictive and dull. But through prioritizing the human nature and achievements through the history we are able to define the judging criterion for "IT paradigm as a means". For example, when the educational goal is sensational development of students it is essential for them to connect with the nature through their body, as the locus of emotional expression and the activities like jogging and playing in the nature are of high importance. In attaining such a goal, virtual education could not offer much help by its own. In such conditions the ideas such as Sparta education and the philosophical ideas of philosophers like Marcel who claims that "I am the body" (Schrag, 2003) and other existence philosophers could be helpful.
It seems that by restraining the range of effects produces by IT and regarding it as one achievements the same as many other achievements of human culture and civilization, we are equipped by a novel cultural tool for our higher education.

The final necessity is a taking a holistic view in application of IT instead of a one-dimensional technical view. In employing the IT in higher education we should take a holistic view. As it seems in some aspects of human life the main issue related to IT is the technical issue. For example, in the field of business and banking the main concern is further development of technical structures and full achievement of electronic business and banking. In the field of education the subject is human being with all of his natural dimensions and complexities. The expansion of IT should also be investigated and developed in line with these dimensions and complexities. The virtual education in higher education should not be taken as the basis for technical reforms but its relationships to educational goals should be revealed; the goals that are inferred from concepts such as life meaning, the nature of social interactions, ethical commitment and values.

Following the discussion, the educational, ethical and social essentiality and consequences of virtual education must be investigates with regard to universal and local criteria. Prior to the application of virtual education the background for considering these consequences by teachers and students should be included in the curricula. A course as "The Philosophy of Virtual Education" could be included in teacher training programs for teachers and for the students some discussions on the criticizing the present technological conditions could be included in the curricula during the process of virtual education according to real and tangible consequences (like cultural, social and ethical consequences of using cell phone and Internet). These discussions might be presented as a more specialized course of "The Philosophy of IT" in graduate programs.

Finally and to put it short, virtual education is not a whole education hence it could not and should not, replace the face to face and personal education rather it must enrich the educational experiences of the students.

\section{REFERENCES}

Blake, N., 2003. The Blackwell Guide to the Philosophy of Education. 1st Edn., John Wiley and Sons, Blackwell, Oxford, ISBN-10: 0631221190, pp: 414.

Borgmann, A., 2000. Holding on to Reality: The Nature of Information at the Turn of the Millennium. 1st Edn., The University of Chicago Press, Chicago. ISBN-10: 0226066231, pp: 282. 
Cheserbo, J.W., 1999. Communication Technologies as Symbolic form: Cognitive Transformations Generated by the Internet. Bus. Inform.

Craig, E., 2005. The Shorter Routledge Encyclopedia of Philosophy. 1st Edn., Routledge, London and New York, ISBN-10: 0415324955, pp: 1077.

Dreyfus, H.L. 2009. On the Internet. 2nd Edn., Taylor and Francis, Abingdon, UK, ISBN-10: 0415775167, pp: 168.

Dreyfus, H.L. and C. Spinosa, 1997. Highway bridges and feasts: Heidegger and borgmann on how to affirm technology. Continental Philosophy Rev., 30: 159-178.

Edmund, C.S., 1991. Forms of Curriculum Inquiry. 1st Edn., State University of New York Press, New York, ISBN-10: 0791406490, pp: 336.

Given, L.M., 2008. The Sage Encyclopedia of Qualitative Research Methods. 1st Edn., Sage Publications, Los Angeles, Calif., ISBN-10: 1412941636, pp: 1014.

Hamrah, S.Z. and M.R. Behrangi, 2010. The social objectives of educatiion in views of jaspers and the role of virtual education. Tarbiat Moallem University.

Hanks, C., 2009. Technology and Values: Essential Readings. 1st Edn., John Wiley and Sons, Chichester, UK., ISBN: 1405149000, pp: 542.

Heidegger, M. and J. Stambaugh, 1996. Sein und Zeit. 1st Edn., SUNY Press, Albany, New York, ISBN: 0791426777, pp: 487.

Jaspers, K., 1989. Philosophy and the World: Selected Essays and Lectures. 1st Edn., Regnery Gateway, Washington, D.C., ISBN: 0895267578, pp: 314.

Jaspers, K., 2003. Reason and Existenz. 1st Edn., Textbook Publishers, ISBN: 0758176147, pp: 157.

Jaspers, K., 2009. Man in the Modern Age. 1st Edn., Routledge, London and New York, ISBN: 0415570611, pp: 212.

Kierkegaard, S., 2010. The Present Age: On the Death of Rebellion. 1st Edn., HarperCollins, New York, London, ISBN-10: 0061990035, pp: 128.

Ladriere, J., 1998. The technical universe in an ontological perspective. Intl. J. Technol., 41: 66-91.

Laurie, R.M., 1997. Virtual reality: An empiricalmetaphysical test bed. J. Comput. Mediated Commun.
Lyotard, J.F., 1984. The Postmodern Condition: A Report on Knowledge. 1st Edn., University of Minnesota Press, Minneapolis, ISBN: 0816611734, pp: 110 .

Marcel, G., P. McCormick and S. Jolin 1980. Tragic Wisdom and Beyond. 1st Edn., Northwestern University Press, Evanston, ISBN-10: 0810106140, pp: 256.

Marcel, G., P.A. Schilpp and L.E. Hahn, 1984. The Philosophy of Gabriel Marcel. 1st Edn., Open Court, US, ISBN: 0812691512, pp: 624.

Marcuse, H., 2002. One-Dimensional Man: Studies in the Ideology of Advanced Industrial Society. 2nd Edn., Routledge, London, New York, ISBN-10: 0415289777, pp: 336.

Murphy, J.W. and J.T. Pardeck, 1985. The technological world-view and the responsible use of computers in the classroom. J. Educ., 167: 98117.

Nietzsche, F.W., A.D. Caro and R.B. Pippin, 2006. Nietzsche: Thus Spoke Zarathustra. 1st Edn., Cambridge University Press, Cambridge, ISBN-10: 0521602610, pp: 270.

Prosser, B.T. and A. Ward, 2000. Kierkegaard and the internet: Existential reflections on education and community. Int. J. Ethics Inform. Technol., 2: 167180. DOI: $10.1023 / \mathrm{A}: 1010005605872$

Pagani, M., 2005. Encyclopedia of Multimedia Technology and Networking. 1st Edn., IGI Global Snippet, Italy, ISBN-10: 1591405610, pp: 650.

Rihoux, B., 2006. Qualitative Comparative Analysis (QCA) and related systematic comparative methodsrecent advances and remaining challenges for social science research. Intl. J. Int. Soc., 21: 679-706. DOI: 10.1177/0268580906067836

Sartre, J.P., 1969. Being and Nothingness: An Essay in Phenomenological Ontology. 5th Edn., Taylor and Francis, New York, ISBN-10: 0806522763, pp: 553.

Schrag, C.O., 2003. Communicative Praxis and the Space of Subjectivity. 1st Edn., Purdue University Press, Indiana, ISBN-10: 1557533016, pp: 219. 